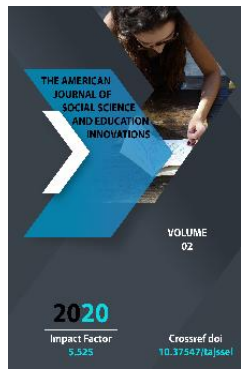

\title{
An Artistic Depiction Of English And Uzbek National Traditions
}

Copyright: Original content from this work may be used under the terms of the creative commons attributes 4.0 licence.

Sainazarova Makhliyo Asatullayevna

English Teacher, National University Of Uzbekistan Named After Mirzoulug'bek , Uzbekistan

\section{ABSTRACT}

Western and Eastern world have different thoughts about traditions and people in a scene across various cultural groups indicating a universal principle of preference. In this article, weexplorethe differences between English and Uzbek national traditions in the works of the English writer Jane Austen and the Uzbek writer Abdullah Qadiri.

\section{KEYWORDS}

National tradition, English and Uzbek literature, culture, customs

\section{INTRODUCTION}

Today, as at start of the XXI century, the role of tradition in orienting, or perhaps even in fashioning, the individual. Tradition is under assault, we are told, by market forces, global integration, and the ubiquitous media. Marxist and postmodern thinkers have even suggested that under such conditions, all traditions must be somewhat inauthentic - the product of conscious fashioning, and, thus, not really a tradition at all. At times, traditionalists have called for group rights and group protections in an attempt to prevent commerce from eroding tradition, and thus, they hope, they can avoid the postmodern critique entirely. For cultures all over the world, textiles play an important role in carrying on history and society. Artistic traditions that have lasted for centuries are expressed and passed down through the 
fabrics of culture.Traditions are and always have been opportunities for creativity, appropriation, and self-conscious cultural critique

A tradition is a belief or behavior (folk custom) passed down within a group or society with symbolic meaning or special significance with origins in the past.A component of folklore, common examples include holidays or impractical but socially meaningful clothes (like lawyers' wigs or military officers' spurs), but the idea has also been applied to social norms such as greetings. Traditions can persist and evolve for thousands of years-the word tradition itself derives from the Latin tradere literally meaning to transmit, to hand over, to give for safekeeping. While it is commonly assumed that traditions have ancient history, many traditions have been invented on purpose, whether that be political or cultural, over short periods of time. Various academic disciplines also use the word in a variety of ways.

\section{THEORITICAL PART}

The concept of tradition, as the notion of holding on to a previous time, is also found in political and philosophical discourse. For example, it is the basis of the political concept of traditionalism, and also strands of many world religions including traditional Catholicism. In artistic contexts, tradition is used to decide the correct display of an art form. For example, in the performance of traditional genres (such as traditional dance), adherence to guidelines dictating how an art form should be composed are given greater importance than the performer's own preferences. A number of factors can exacerbate the loss of tradition, including industrialization, globalization, and the assimilation or marginalization of specific cultural groups. In response to this, traditionpreservation attempts have now been started in many countries around the world, focusing on aspects such as traditional languages. Tradition is usually contrasted with the goal of modernity and should be differentiated from customs, conventions, laws, norms, routines, rules and similar concepts.

Abdullah Qadir: Abdullah Qadir'sworks arean example of artisticmastery.In these works, the main idea is alwaysclearly expressed such as people and their living conditions are depicted as if in front of our eyes, the subject ofthese works are always interesting and rich in language.It is clear from Qadir's language that he knew the rich and wonderful language of the people very well and his novels are written in beautiful style.A.Qadir appeared in the press with his short poems, articles and comics. He wrote poems such as "Our Condition", "To My Nation", the play "The Unhappy Groom", "The Young Man", "In the Capricorn", "Feast of Demons" and others.In all his works, like all modern artists, heinspired readers to goodness, knowledge and enlightenment.

The author's story "In the Capricorn" captures the old traditions that hinder progress and the spirit of the crowd that remains in the shell of the scribe.Millions, tens of millions of peoples are drawn into the whirlpool of World War II, while their fate is being decided, and the people are obsessed with, and enjoy, habits like the Capricorn and kupkari.In this work, the author not only tells the story, but also presents to the reader a unique image and biography of each character.He tells the story in the language of an impartial teenager.The protagonist is a child who is just starting his independent life, riding a horse, entering the crowd, looking at everything with great interest and amazement, but unable to get to the bottom of adult life, rituals, events.Oybek 
described the story "Uloqda" as a great achievement not only of Abdullah Qadir, but also of Uzbek storytelling in the 1910s.This shows that the author has confidently taken a big step towards realism in the story.

We all know that the author made a significant contribution to the Uzbek novel with his work "Days gone by" and laid the foundation for the novel.No other means of fully reflecting and preserving the national spirit can be compared to fiction. Realizing this, the writer inhaled this national spirit in his novel The Days gone by and this national spirit is reflected in the fate of the heroes of the work.Speaking about literature, the head of our state has repeatedly said that the national literature should reflect the national spirit.Even modern writers, in their works, emphasize that the breath of the national spirit should be visible in the image and destiny of each of the heroes, and that the nation that has preserved the national spirit will live forever.In 1968, in Berlin, Germany, the novel " Days gone by" was published in German under the title "Lovers of Tashkent".Not just the main characters, but each character in the episode portrays their way of life and destiny in a very beautiful and convincing way. It is also important to know that this novel is full of national freshness. This feature is evident in the internal and external appearance of images, as well as in the depiction of landscapes and subjects.The national tone expressed in the novel serves to enhance the impact of the work.It also gives the reader a lot of interesting information about the customs of our people, customs, ceremonies such as hospitality, weddings.I remember that Kumush's beautiful qualities were always exemplified by girls.

If a girl is born in someone's house, she will be nicknamed Kumushoy by Kumushbibi.It is also a sign of unconditional love for Kumush.
Jane Austen:Jane Austen is one of the most famous English writers who reflects the national traditions of such people in her works.Jane Austen, an English writer, was the first to give the novel its distinctly modern character in relation to ordinary people in everyday life.During her lifetime she published four novels: Emotion and Sensitivity (1811), Pride and Prejudice(1813), Mansfield Park (1814) and Emma (1815). Among them, and in "Persuasion" and "Northanger Abbey," she vividly portrayed the middle-class life of the English in the early 19th century.Her novels marked the moral novel of the period, but two centuries after her death, they became timeless classics that remained critical and popular achievements.Jane Austen's unique literary style is based on a combination of parody, burlesque, satire, free indirect speech, and a level of realism. She uses parody and burlesque in her works to criticize the comedy effect and the image of women in 18th-century sentimental and Gothic novels.Her works, as well as the works of A. Kadyri, are mainly devoted to education.Although Austin abandoned the formal ethical rules prevalent in literature in the early 19th century, the main theme of her works is distinguished by morality, duty to society, and religious seriousness.Jane Austen's first three novels form a separate group that is characterized by a strong element of literary satire in character and humorous depiction of society.They are "Sense and Sensibility", "Pride and Prejudice ", and "Northanger Abbey". Sense and Sensibility tells the story of poor Dashwood sisters. Marianne is the protagonist of 'sensitivity', i.e. openness and enthusiasm. She falls in love with the charming John Willaby, who looks like a romantic lover, but is in fact an unscrupulous wealth hunter. "Pride and Prejudice" depicts a conflict between Elizabeth Bennett, the village gentleman's daughter, and

PRACTICAL PART 
Fitzvilliam Darcy, a wealthy and aristocratic landowner.While Austin shows them are interested in each other, he changes the "first impressions" convention.Ultimately, they unite in love and self-awareness. The intelligent and high-spirited Elizabeth was one of Jane Austen's favorite of all the heroes and one of the most engaged in English literature.Northanger Abbey depicts the satire in the traditional novels of a polite society, as well as tales of Gothic terror.

In his six major novels, Austen explored the "domestic" possibilities by creating a moral comedy of middle-class life in England of his time.His recurring legend of a young woman's journey of self-discovery through the path of love for marriage focuses on easily recognizable aspects of life.This concentration, which is due to the contradictions between his characters and personality and his heroes and their society, connects his novels more to the modern world than to the traditions of the eighteenth century.It is this modernity, along with its prose-style ingenuity, realism, and timelessness, that explains its clever, cheerful empathy, and how it skillfully continues in such beautifully constructed novels.Jane Austen's writings are wonderful and unique, but her personal life is not enviable if we take a closer look at her.The greater the interest in Jane's work today, the greater the interest in her life.If we look at the time in which she lived and worked, we see that the first four works of her writing were published anonymously.In her book Faith, she describes the changes in this society in a wonderful way.Jane died on July 18 , 1817 at the age of .SHe never wrote about love or the unexpected injustices of love.Information about her life could never have given information about Jane's inner world, her unique and quick mind, but this feature of hers is reflected in all of Jane's works.Jane Austen loved social events, and we can learn from her letters about her involvement in such events.

\section{CONCLUSION}

In short, the work of art contains different ideas and concepts about the transmission of national traditions.With the help of these theories and concepts, in our selected works, we have considered at least a little how English and Uzbek writers have revealed national traditions.

\section{REFERENCES}

1. Kushjanov $M$. Describing arts of Abdulla Qodiri. T .: Fan, 1966.

2. Karimov B. The problem of interpretation in the Uzbek literature of the 2oth century (on the example of Qadiri). FFD dissertation, T., 2002

3. Butler, Marilyn. Jane Austen and the War of Ideas. 1975 and 1987. Oxford: Oxford University Press

4. Devlin, D. D. Jane Austen, and Education. London: Macmillan 1975.

5. Yves Congar (October 2004). The meaning of tradition. Ignatius Press.

6. Langlois, S. (2001). "Traditions: Social". International Encyclopedia of the Social \& Behavioral Sciences. pp. 15829-15833.

7. Pascal Boyer (1990). Tradition as truth and communication: a cognitive description of traditional discourse. Cambridge University Press 